\title{
ON DILEMMAS AND SOLUTIONS FOR THE ISSUES OF HIGH SEAS MARINE PROTECTED AREAS DURING THE BBNJ NEGOTIATION
}

\author{
WANG, Y. \\ East China University of Political Science and Law \\ No. 1575 Wan Hangdu Road, 200042 Shanghai, China \\ (Received $8^{\text {th }}$ Mar 2019; accepted $21^{\text {st }}$ May 2019)
}

\begin{abstract}
This study aims to discuss the dilemmas and solutions for the issues of high seas marine protected areas during the BBNJ negotiation. It expounds the dilemmas of BBNJ negotiations on the issue of MPAs (such as there is no single universally agreed definition of MPAs, the selection criteria for MPAs are still not clear and no clear consensus on the designation process of MPAs), analyzes the reasons for dilemmas of MPAs in the process of BBNJ negotiations and proposes the solutions of main issues in the process of BBNJ negotiations. The result of this research is that MPAs, as a breakthrough to the traditional marine management tools, are becoming an important means for the international community to protect marine biodiversity. Finally, it concluded that after dealing with dilemmas of lack of definition, unclear selection criteria and disputes over the governance model, the negotiation of the issue of MPAs in ABNJ will inevitably reach a reasonable institutional framework, and further promote marine biodiversity protection.
\end{abstract}

Keywords: marine biological diversity, global governance model, international instrument, marine resources, alternative management approach

\section{Introduction}

Since the end of $20^{\text {th }}$ century, MPAs, as alternative management approach of marine resources, have been proposed to remedy the defect of traditional marine management methods and to be established in large numbers. Among them, those established on the high seas or other areas beyond national jurisdiction are collectively referred to as marine protected areas beyond national jurisdiction (hereinafter referred to as "ABNJ marine protected areas"). While emphasizing the protection of the marine environment, ABNJ marine protected areas usually restrict the rights of countries to exploit and utilize marine resources to a certain extent. During the four Pre-committee meetings and the first BBNJ Intergovernmental Conference in 2018, as an important part of the ILBI, the issue of $\mathrm{ABNJ}$ marine protected areas has induced an intense debate between countries or groups of countries concerned. The purpose of this research is to discuss the dilemmas and solutions during the BBNJ negotiation for the issue of High Seas Marine Protected Areas.

\section{Methods}

\section{Dilemmas of BBNJ negotiations on the issue of MPAs}

At its $47^{\text {th }}$ meeting, the Preparatory committee adopted the recommendations, which clearly stated that the text of ILBI would set out objectives of area-based management tools, including marine protected areas, relationship to measures under relevant instruments, frameworks and bodies, process, implementation, monitoring, and review (Afonso et al., 2018; Sufiyan et al., 2018). Most countries expressed their positions and 
suggestions regarding the definitions of MPAs, objectives and principles, criteria, governance, and institutional mechanisms. By sorting out the positions of all sides, we can conclude that the current BBNJ negotiations are mainly facing the following dilemmas:

\section{There is a dispute on the definitions for MPAs}

Given that the definition of MPAs is the logical starting point for other issues related, it should be clear in the negotiations. Whether the ILBI defines the MPAs in ABNJ or not and its general definition leads to contention among parties.

With regard to this issue, some states supported that the ILBI should be based on existing concepts, such as the definition of the CBD Technical Expert Group on Marine and Coastal Protected Areas or the IUCN's definition of MPAs. Others suggested that the MPA definition should be sufficiently broad to encompass specific types of conservation and impact restrictions, for example, High Seas Alliance favored adapting CBD and IUCN definitions, also including cultural values. However, the North-East Atlantic Fisheries Commission (NEAFC) underscored that ABMTs by RFMOs are functioning well and that the ILBI should enhance harmony between tools of different sectoral bodies, rather than define ABMTs (Alger and Dauvergne, 2017; Khanchoul et al., 2018). It is noteworthy that Costa Rica suggested a working concept of MPAs as "a clearly defined geographic space recognized, dedicated and managed through legal and other effective means to achieve the conservation of biodiversity, ecosystem services, and other cultural values."

\section{The selection criteria for MPAs are still not clear}

The so-called selection criteria for designing marine protected areas mainly refer to which scientific standard should be introduced to estimate the level of biodiversity, in order to further evaluate whether an area needs to protect and what the extent of protection should be deleted. The selection criteria for MPAs are vital to determine the location and geographic scope of MPAs, constituting a basis for the establishment of $\mathrm{ABNJ}$ marine protected areas.

Many countries proposed to draw lessons from the EBSA (ecologically or biologically significant marine areas) criteria, and CBD guidelines on MPA networks (Ayer et al., 2018; Ilyas et al., 2018). Others noted that criteria would vary depending on the regional circumstances and should include, inter alia, biological productivity and/or diversity (Ban et al., 2017; Rahim et al., 2018). In addition, countries called for establishing MPAs in vulnerable areas and important areas for certain species (Cabral et al., 2017; Abdullah and Rahim, 2018). The positions of countries on this issue were dispersed, and the main dispute lies in which scientific criteria should be introduced into the ILBI.

However, the preparatory committee just listed the criteria which belong to existing criteria that countries proposed during the discussion. Thus, there were still a lack of unified selection criteria for MPAs finally and the issue of selection criteria would be further discussed at the intergovernmental conferences. 


\section{No clear consensus on the designation process of MPAs}

In the substantive recommendations, the preparatory committee summarized the proposal, consultation on and assessment of the proposal, decision-making as the issue of the designation process.

In terms of the proposal, the dispute on the issue is whether the international organizations can be authorized to submit a proposal for the establishment of MPAs, but the preparatory committee did not explain it in the recommendations. Some countries supported that state parties, other organizations, even a scientific and technical body can propose to establish MPA (Carr et al., 2017; Sarwar at al., 2018). Other countries consider that the proposal of MPAs should be put forward by state parties individually or jointly, but they did not mention whether international organizations can enjoy the right to submit proposals. For example, the EU highlighted that proposals to designate or recognize MPAs should come from state parties, individually or as a group. Though Japan, Argentina and Sweden had the generally same position as the EU, they emphasized on adequate communication with stakeholders prior to the proposal (Dias et al., 2017; Majumder et al., 2019). The US also underscored lack of clarity regarding who can submit proposals (Duarte et al., 2017).

With respect to consultation on and assessment of the proposal, a major point of dispute is whether ILBI needs to establish an independent global body to decide on proposed MPAs. For this issue, the US, supported by Canada and Australia, favored referring to a "scientific process," rather than a "scientific committee," providing input to "policy making," instead of a policy-making "body" (Feng et al., 2017). By contrast, most of the countries called for creating a scientific subsidiary body to technically assess proposals (Ferrari et al., 2018). Hence, no consensus has been reached on the establishment of a new scientific body at the global level.

In respect of decision-making, divisions mainly lie in whether establish a decisionmaking body or entitle existing regional institution to decide on MPAs proposals. The African Group, supported by the EU, called for global-level, consensus-based decisionmaking on ABMTs (Area-Based Management Tools) or MPAs (Gonson et al., 2017; Nouaim et al., 2019). However, Australia preferred a regional action-oriented process, including regional decision-making and Norway, supported RFMOs and the ISA designating and implementing MPAs (Havermans et al., 2018). Moreover, the Russian Federation opposed the creation of a new global mechanism for creating ABMTs and Norway noted lack of consensus on creating a new organization for establishing ABMTs during the fourth session of the preparatory committee (Hughes and Grant, 2017). To sum up, there are many countries opposed the global mechanism for MPAs.

\section{Discussion}

\section{Analysis of the reasons for dilemmas of MPAs in the process of BBNJ negotiations}

\section{There is no single universally agreed definition of MPAs}

As an instrument for marine biodiversity conservation and sustainable use, MPAs have been receiving increasing attention from policymakers. A reasonable concept of marine protected areas should include at least three elements: clear objectives, scope, and management measures. But there is a lack of a definition accepted by most countries in the international community. 
At the level of the global treatise, no conventions clearly defined the concept of MPAs in their text, but there are several related concepts similar to MPAs. For example, according to the Convention on Biological Diversity (CBD), "protected areas" means a geographically defined area which is designated or regulated and managed to achieve specific conservation objectives (Jabou and Smith, 2018). But the concept of "protected areas" is different from the concept of "marine protected areas", especially the concept of "marine protected areas beyond national jurisdiction". In 2004, the CBD conference of the parties adopted the Decision VII/5, defined "marine and coastal protected areas" as "an area within or adjacent to the marine environment, together with its overlying waters and associated flora, fauna, and historical and cultural features, which has been reserved by legislation or other effective means, including custom, with the effect that its marine and/or coastal biodiversity enjoys a higher level of protection than its surroundings". However, the definition of "marine and coastal protected areas" is still a broad concept that includes "historical and cultural features", which remains further discussion for applying to ILBI. The Convention Concerning the Protection of the World Cultural and Natural Heritage which has been ratified by 193 states parties, defined the "natural heritage" as "natural features consisting of physical and biological formations or groups of such formations, which are of outstanding universal value from the aesthetic or scientific point of view; geological and physiographical formations and precisely delineated areas which constitute the habitat of threatened species of animals and plants of outstanding universal value from the point of view of science or conservation; natural sites or precisely delineated natural areas of outstanding universal value from the point of view of science, conservation or natural beauty." It can be seen that the concept of "natural heritage" not only emphasizes the protection of the habitat of threatened species but also the value of aesthetic. Hence, a definition of MPAs is absent at the level of global treatise.

At the level of regional frameworks or bodies, The International Convention for the Prevention of Pollution from Ships, 1978 (MARPOL 78) that was developed by the International Maritime Organization (IMO), defining the "Special Areas" as "a sea area where for recognized technical reasons in relation to its oceanographical and ecological condition and to the particular character of its traffic the adoption of special mandatory methods for the prevention of sea pollution by oil is required" (Kay and Butenschön, 2018). In 1991, IMO introduced a new concept called "Particular Sensitive Sea Area (PSSA)" to protect the marine environment and ecosystem (Laffoley and Freestone, 2017). Moreover, in 2011, the Council of the international seabed authority proposed an environmental management plan in the area of the Clarion-Clipperton Zone to protect the biodiversity and ecosystem structure. In this plan, the international seabed authority adopted the term of "Area of Particular Environmental Interest (APEI)", which refers to "protect biodiversity and ecosystem structure and function by a system of representative seafloor areas closed to mining activities." As the report of Secretary-General pointed, a number of expressions are used to refer to the various area-based management tools presently in use, include: "special areas"; "specially protected areas"; "marine protected areas"; "spatial and temporal closures" in the fisheries context; "particularly sensitive sea areas" in the shipping context; "sanctuaries"; and "reserves" (Lambert et al., 2017). Thus, there is no single universally agreed definition of MPAs and the above definitions or concepts similar to "marine protected areas" at the global or regional level cannot be viewed as the concept of MPAs essentially, but they may only offer references for the ILBI. 
The reasons for lacking a universally accepted definition for MPAs, in my opinion, mainly are as follows:

First, the history of MPAs is relatively short, which leads to the understanding of countries to MPA is still in its infancy. The global extent of MPAs only really began to increase significantly from the late 1970s, notably with the declaration of the Great Barrier Reef Marine Park in Australia (Lathrop et al., 2017). Furthermore, the proportion of marine protected areas to the total ocean area increased from only 0 to $3 \%$ between 1960 and 2013, compared with less than 1\% in 1990 (Madrigal et al., 2017). While MPAs in ABNJ emerged later and the first Pelagos Sanctuary, which is designated in 1999 and is not absolutely located in the high seas. It can be seen that the management tool of MPAs not only has a relatively short history, but the process of development is slow, which leads to the lack of a more unified understanding of MPA among countries. For instance, even though the US with the world's largest exclusive economic zone and has established over 1700 MPAs, its definition of MPAs is different from the definition used by the World Conservation Union (IUCN) (Mazaris, 2017).

Second, MPAs can be classified into different types according to their purpose, which may easily cause some misalignment of understanding in different countries. In fact, MPAs can be further divided into 5 different types, each of them is: (1) MPAs for purpose of fishery management and resources conservation; (2) the marine development zone for purpose of ecosystem or habitat conservation; (3) MPAs for purpose of marine biodiversity conservation; (4) MPAs for purpose of rare or endangered species preservation; (5) MPAs for tourism, entertainment, education and scientific research. Moreover, the International Union for Conservation of Nature (IUCN) divided MPA into six types, depending on their objectives: (1) Strict Nature Reserve/Wilderness Area; (2) National Park; (3) Natural Monument; (4) Habitat/Species Management Area; (5) Protected Landscape/Seascape; (6) Managed Resource Protected Area (Mcneill et al., 2018). Consequently, some countries may have only established the single type of MPAs mentioned above, while others may have established several different types of MPAs at the same time, resulting in an inconsistent understanding of MPAs among countries.

Finally, there are still a few countries in the world have the capacity to establish and manage MPAs effectively. Most countries are too inexperienced to establish MPAs, especially the large-scale MPAs. According to statistics, there are more than 70 countries in the world including China, Indian and Canada, whose area of MPAs is less than $1 \%$ of their exclusive economic zones, while just only 14 countries' MPAs account for more than $10 \%$ of their exclusive economic zones. In addition, according to statistics, it can also be concluded that countries with the capacity and experience in establishing very large MPAs are just limited to several countries, such as Australia, Russia, the US, New Zealand, the United Kingdom and France (Mrema, 2017). Judging from the current practice, the four "high seas MPAs" are only a short period of 5 to 15 years, which is slightly short-lived and the actual effect is not obvious. However, MPAs established by the ILBI are precisely those large-scale pelagic marine protected areas, so most countries are in fact lack of experience in setting up such MPAs and not to reach an agreement on the definition of MPAs.

\section{A variety of selection criteria have made ILBI difficult to choose and coordinate}

On the premise of defining MPAs, it's necessary to further define the selection criteria for MPAs. At present, the existing selection criteria for MPAs mainly include 
scientific criteria for identifying ecologically or biologically significant marine areas (EBSA), guidelines on designating a "particularly sensitive sea area" (PSSA), vulnerable marine ecosystems (VME) criteria, the general design guidelines for area of particular environmental interest (APEI), key biodiversity areas (KBA) adopted by IUCN and etc. The ILBI would eventually choose a set of selection criteria, but now there are at least 7 set of selection criteria with different elements that make the ILBI difficult to choose and coordinate.

From the regional organizations or bodies of these selection criteria, different types of selection criteria are proposed and implemented by different international organizations that they have seldom interaction with each other. From the emphasis of these selection criteria, different priorities lead to the different selection criteria. For instance, the criteria of VME pays the more attention to the ecological damages caused by deep-sea fisheries. Thus, the FAO proposed a distinct standard from the EBSA, named "Functional significance of the habitat" which is to protect habitats that are necessary for the survival, function, spawning/reproduction or recovery of fish stocks. In addition, the application scope and the amounts of the region selected by these criteria are also different. The VME has been adopted by some regional fishery management organizations, such as NEAFC, CCAMLR, NAFO GFCM, SEAFO and SPRFMO. Currently, IMO has also designated 17 particularly sensitive sea areas around the world, most of which are located within national jurisdiction. The EBSA description work is also constantly updated and deepened, 71 out of 279 ecologically or biologically significant areas (EBSAs) are located in ABNJ, covering $21 \%$ of total surface area of ABNJ (Nikitine et al., 2018). It can be seen that the inconsistencies and even coincidences in the scope of different selection criteria have made it difficult for ILBI to determine the selection criteria.

Given that the ILBI should coordinate the relationship of different selection criteria for MPAs or other area-based management tools and prevent duplication, the negotiations of the ILBI are actually facing the dual difficulty in choosing and coordinating the selection criteria. In fact, the relationship between choosing and coordinating is like the two sides of the coin. It is manifested that when making the final decision on the issue of selection criteria, it is necessary to make trade-offs between existing criteria and avoid conflicts with existing criteria. Therefore, the situation of dual difficulty faced in determining the selection criteria is an important reason for the delay in reaching a consensus on this issue during the BBNJ negotiations.

\section{MPAs in ABNJ will impose a significant impact on some states'fishery interests}

The designation process is directly related to the management model of MPAs. In the third session of the preparatory committee, Chair Duarte proposed focusing on three options: a global model, a hybrid model and a regional and sectoral model (Pereira et al., 2018). Specifically, the states with skeptical and negative views on the global model are Australia, New Zealand, Norway, Iceland, Russia, Canada and the Pacific small island developing States (PSIDS). These states undoubtedly all advocated the leading role of regional organizations in the establishment of ABNJ marine protected areas and considered that excessive intervention from the global level should be reduced or avoided. The regional and sectoral model means to essentially authorize the regional fisheries management organizations (RFMO) the decision-making powers for initiating and managing a high seas MPA. However, whether the regional fisheries management organizations or bodies actually establish an ABNJ marine protected area in accordance 
with the ILBI depends on the will of the all contracting parties of the organizations and their internal decision-making rules.

At present, there are many regional fisheries management organizations, including the Commission for the Conservation of Antarctic Marine Living Resources (CCAMLR), Northwest Atlantic Fisheries Organization (NAFO), the North East Atlantic Fisheries Commission (NEAFC), the South East Atlantic Fisheries Organization (SEAFO), The South Pacific Regional Fisheries Management Organization (SPRFMO), the North Pacific Fisheries Commission (NPFC), the Western and Central Pacific Fisheries Commission (WCPFC), the Southern Indian Ocean Fisheries Agreement (SIOFA), the General Fisheries Commission for the Mediterranean (GFCM) and etc.

The current governance model of high seas fisheries is mainly relied on regional fisheries management organizations and there are 20 regional fishery management organizations with mandate, covering the main fishing areas of the global ocean. In respect to the number of the contracting parties, members of the CCAMLR currently include 24 States and the European Union, NAFO has 12 Contracting Parties, the NEAFC has 5 contracting parties and 5 non- cooperating contracting parties, the SEAFO has 7 contracting parties, the SPRFMO has currently 15 Members, the NPFC has 8 contracting parties, the WCPFC has 26 contracting parties, the SIOFA has 9 contracting parties and the GFCM has 24 contracting parties. To sum up, despite the WCPFC has the largest number of the contracting parties among the regional fisheries management organizations mentioned above, but it only has the 26 contracting parties. Among the countries that do not approve of the global model, Norway, Iceland, Russia and Canada are all members of NAFO, while Norway, Iceland and Russia are also parties to NEAFC (Wu, 2018). Therefore, the leadership of establishing the high seas MPAs is easily controlled by the RFMO that is represented by a few states.

From the states with skeptical and negative attitude to the global model, their capture production of fisheries usually depends heavily on the single region under the management of the RFMO. For example, Norway, Iceland, Russia and Canada are all the contracting parties of the NAFO, while Norway, Iceland and Russia are also the members of the NEAFC at the same time. Australia and New Zealand are both contracting parties of the WCPFC and the SPRFMO. According to the statistics of FAO in 2016, total capture production of Norway is 203,8810 tons in the area of Northeast Atlantic, accounting for $92 \%$ of its annual total capture production; It is worth noting that the geographic scope of FAO fishing area 27 is the same to the areas of the NEAFC Convention. Furthermore, all the capture production of Iceland in 2016 come from the area of Northeast Atlantic; The capture production of Canada in the Northwest Atlantic is 663,680 tons, accounting for $78 \%$ of its annual total capture production; In addition, the capture production of New Zealand in the Northwest Pacific is 421,646 tons, accounting for $99 \%$ of its annual total capture production (Plassjohnson et al., 2017). However, as the country with the highest capture production of fisheries in the world, China's marine fisheries production in 2016 was 15,331,960 tons, but the $97 \%$ of the total annual production came from the Northwest Pacific. According to the "13 ${ }^{\text {th }}$ FiveYear Plan" issued by the Ministry of Agriculture in 2017, by the end of 2016, the total production of China's far-off ocean fisheries was 1.99 million tons, including 1.32 million tons of high seas fisheries. Hence, China's fishery production on the high seas only accounts for $8 \%$ of its annual marine capture production and the fishing area 
of China in Northwest Pacific is not entirely within the scope of regional fisheries management organizations.

From the decision-making mechanism of the relevant regional fisheries organizations, the NEAFC and the SPRFMO, which are composed mainly of states with negative attitude to the global model as mentioned above, provided for their respective decision-making mechanisms. According to the NEAFC Convention, decisions of the Commission shall be taken by a simple majority or by a two-thirds majority (Postaire et al., 2017). The SPRFMO Convention provided that decisions by the Commission shall be taken by consensus (Schulze et al., 2017). It can be concluded that the decisionmaking mechanism of regional fisheries management organizations has an obvious dependence on the will of the members. When the contracting parties hold different or opposing positions on the proposals, the regional fisheries management organizations will not effectively make a decision and implement it. Furthermore, the Objection Procedure is also prevalent in regional fisheries organizations, as long as members formally raise objections during the decision-making process of regional fisheries management organizations. This procedure has led regional fisheries organizations to reach the consensus of all members so as to a better compliance. Therefore, if the ILBI authorizes the RFMO the autonomy to establish MPAs, it is the same as granting the minority contracting parties of these RFMO the right to establish MPAs.

The establishment of the high seas MPAs will inevitably impose restrictions on the fishing activities, for example, the conservation measures of the Ross Sea established in 2016 provided for "fishing activities are prohibited within the MPA" (Soares and Lucas, 2018). Thus, the states whose fishery productions highly depend on the single region under the management of the RFMO do not hope it adopts the decision to establish MPA. To this end, from external relations, these fishing nations of the RFMO will emphasize the role of RFMO in the BBNJ negotiations and tend to retain their respective autonomies in establishing the $A B N J$ marine protected areas. From the internal relations of the RFMO, these states will also make full use of the decisionmaking mechanism in order to minimize the impact of MPAs on their fishing interests.

\section{Results}

\section{The solutions of main issues in the process of $B B N J$ negotiations}

\section{The ILBI should clarify the definition of MPAs on the basis of existing definitions}

The definition of MPAs not only should be clarified in the process of BBNJ negotiations but also defined in the ILBI. As an important newly emerging marine management measure, the concept of MPAs is not clearly defined in the existing international conventions, including the UNCLOS and there is no universally accepted concept of MPAs in the international community. When the UNCLOS was enacted between 1973 and 1982, marine biodiversity beyond national jurisdiction did not attract the attention of all countries, leaving many gaps in the Convention. Thus, the legal and institutional frameworks that govern marine biodiversity in areas beyond national jurisdiction $(\mathrm{ABNJ})$ are widely perceived as inadequate for ensuring the long-term health and equitable use of the living resources of this vast area and the ILBI should fill the gaps of UNCLOS (Solovyev et al., 2017). Therefore, before creating an MPA system in the ILBI, country participants must agree on what they understand by this term. 
According to the definition of IUCN, it comprises both legal approaches and other approaches; it can be applied in three-dimensional scope of protection, including not only the intertidal zone or the sub-tidal zone of the ocean, but also the seabed environment within this scope; the protection objectives are also broad, including historical and cultural features (Urra et al., 2018). Strictly speaking, the historical and cultural features of the IUCN's definition are not consistent with the objective of protecting marine biodiversity. The definition of protected areas in CBD is an ambiguous definition that does not specify the objectives and management methods of MPAs, and whether the nature of the management methods adopted is a "no-take" MPAs. The OSPAR Commission established by the Convention for the Protection of the Marine Environment of the North-East Atlantic (OSPAR Convention) defined the "marine protected areas" as "an area within the maritime area for which protective, conservation, restorative or precautionary measures, consistent with international law have been instituted for the purpose of protecting and conserving species, habitats, ecosystems or ecological processes of the marine environment." Despite the definition of the OSPAR Commission has the elements of objectives, geographic scope and management measures, but it is not clear whether this definition includes MPAs established in the seabed area. However, the MPA networks of the North-East Atlantic are so far consisted by 7 high seas MPAs and 5 of them are located in the seamount or mid-ocean ridge areas (Young and Friedman, 2018). Hence, the ILBI should determine whether the geographic scope of MPAs' definition includes the seabed areas.

In conclusion, the definitions of MPAs mentioned above are more or less unreasonable when applied to the ILBI, so it is difficult to directly copy the existing definitions of MPAs to the ILBI. The intergovernmental conference on an ILBI under the UNCLOS on the conservation and sustainable use of the marine biological diversity of areas beyond national jurisdiction needs to specify the definition of MPA. First, the ILBI should make clear the geographic scope of MPAs' definition, especially whether the scope should include the international seabed areas. Second, the ILBI should set up specific objectives and take proper account of whether the objectives should comprise the characteristic and historical features. Third, it needs to be further clarified whether the management measures in the ILBI should be defined in a general or enumerated way (Tagle, 2018).

\section{The selection criteria for MPAs in the ILBI should draw lessons from the existing criteria}

The possible ways to cope with the dual difficulty that ILBI faced in determining the selection criteria is to draw lessons from the existing criteria and provide for the inclusive criteria for the ILBI. Thus, its necessary to make a comparative analysis of the existing selection criteria.

According to the statistics of the Table 1, despite different organizations have their selection criteria, but the most of the selection criteria are similar and the nine selection criteria mentioned in have almost covered the existing selection criteria for MPAs in the international community. First, most of the definitions of 9 selection criteria in the were clearly defined in Resolution A.982(24) adopted by the $24^{\text {th }}$ Assembly of the IMO, while the remaining selection criteria are defined in decision IX/20 adopted by the conference of the parties to the convention on biological diversity at its $9^{\text {th }}$ meeting. Second, only the operational guidelines for the Implementation of the World Heritage Convention includes the criteria of "historical geomorphological importance". However, 
the so-called "historical geomorphological importance" refers to "the property represents major stages of earth's history, including the record of life, significant ongoing geological processes in the development of landforms, or significant geomorphic or physiographic features" (Bokuniewicz and Jang, 2018). Hence, the criteria of the historical geomorphological importance, in fact, should be excluded when the ILBI set out the selection criteria for MPAs.

Table 1. Correspondence between the CBD EBSA criteria and other international criteria used by IGOs and NGOs (i.e. Birdlife and IUCN) mentioned in this manuscript. Correspondence is indicated by either a check where it exists, an $X$ where it doesn 't, or a? where there is uncertainty or the criteria suite is under review (Tommasi et al., 2017)

\begin{tabular}{|c|c|c|c|c|c|c|c|}
\hline Organization & CBD & FAO & IMO & UNESCO & RAMSAR & Birdlife & IUCN \\
\hline Site criteria & EBSA & VME & PSSA & WHS & RAMSAR & IBA & KBA \\
\hline Year & 2008 & 2009 & 2005 & $\begin{array}{c}1977(\text { first } \\
\text { version) }\end{array}$ & 2004 & $\begin{array}{l}\text { early } \\
1980 \mathrm{~s}\end{array}$ & 2016 \\
\hline Uniqueness or rarity & $\checkmark$ & $\checkmark$ & $\checkmark$ & $\checkmark$ & $\checkmark$ & $\checkmark$ & $\checkmark$ \\
\hline $\begin{array}{l}\text { Special importance for life history } \\
\text { stages of species }\end{array}$ & $\checkmark$ & $\checkmark$ & $\checkmark$ & $\checkmark$ & $\checkmark$ & $\checkmark$ & $\checkmark$ \\
\hline $\begin{array}{c}\text { Importance to threatened or endangered } \\
\text { species }\end{array}$ & $\checkmark$ & $\checkmark$ & $\checkmark$ & $\checkmark$ & $\checkmark$ & $\checkmark$ & $\checkmark$ \\
\hline $\begin{array}{c}\text { Vulnerability, fragility, sensitivity or } \\
\text { slow recovery }\end{array}$ & $\checkmark$ & $\checkmark$ & $\checkmark$ & $\mathbf{X}$ & $?$ & $\mathbf{X}$ & $?$ \\
\hline Productivity & $\checkmark$ & $\mathbf{X}$ & $\checkmark$ & $\checkmark$ & $\mathbf{X}$ & $\mathbf{X}$ & $?$ \\
\hline Biodiversity & $\checkmark$ & $\mathbf{X}$ & $\checkmark$ & $\checkmark$ & $\checkmark$ & $\mathbf{X}$ & $?$ \\
\hline Naturalness & $\checkmark$ & $\mathbf{X}$ & $\checkmark$ & $\checkmark$ & $\checkmark$ & $\mathbf{X}$ & $?$ \\
\hline Structure & $\mathbf{X}$ & $\checkmark$ & $\checkmark$ & $\mathbf{X}$ & $\mathbf{X}$ & $\mathbf{X}$ & $?$ \\
\hline $\begin{array}{c}\text { Historical geomorphological } \\
\text { importance }\end{array}$ & $\mathbf{X}$ & $\mathbf{X}$ & $\mathbf{X}$ & $\checkmark$ & $\mathbf{X}$ & $\mathbf{X}$ & $\mathbf{X}$ \\
\hline
\end{tabular}

Third, the criteria of "Uniqueness or rarity", "Special importance for life history stages of species" and "Importance to threatened or endangered species" are all stipulated in the existing selection criteria lists and the criteria of "Biodiversity" and "Naturalness" are also adopted by four selection criteria. Hence, these criteria have been accepted by the international community. Fourth, 15 specific selection criteria were listed in the recommendations of the preparatory committee, of which five are beyond the scope of the existing criteria, namely "Representativeness", "Dependency", "Connectivity", "Ecological processes" as well as "Economic and social factors." These five selection criteria need to be further discussed during the intergovernmental conferences. Finally, no matter what selection criteria are adopted by the ILBI, the activities of identifying MPAs are in fact the scientific exercise, which should not be regarded as bringing about any potential management measures and any obligations to establish MPAs. Therefore, the issue of selection criteria for MPAs under the ILBI should be strictly distinguished from the establishment, management, review of MPAs, so that it can continue to be the scientific exercise and provide references for the establishment of MPAs.

To sum up, under the premise of the scientific activities, the ILBI should coordinate the different existing criteria and draw lessons from the regional practice, providing for a set of comprehensive and unified selection criteria for the high seas MPAs. 


\section{The ILBI should adopt the global model for the high seas MPAs}

The adoption of the General Assembly resolution evinces a growing recognition within the international community that the regime governing the marine biodiversity in $\mathrm{ABNJ}$ is no longer fit for purpose, and that further action to develop a legal and institutional framework is necessary (Wang et al., 2018). The global model has obvious advantages compared with the hybrid model or regional and sectoral model.

First, a treaty shall not create either obligations or rights for a third State without its consent in pursuant to Article 34 of Vienna Convention on the Law of Treaties and this provision is also considered to be a customary international law rule. Therefore, the management measures of MPAs adopted by regional organizations or institutions cannot generally create obligations for third states without its consent. The number of Parties in each regional organization or institution under the regional model is far less than those of a universally representative global convention. Hence, the MPAs in ABNJ under the regional model will not be able to directly restrict non-Parties, which will result in the management measures of MPAs cannot be universally observed and regional model have deficiencies in the general principles of international law.

Second, a regional and sectoral model is unable to take unified actions at the global level and are likely to further deepen the fragmentation of marine biodiversity protection beyond national jurisdictions, thus making cooperation and coordination between different regions or sectors more difficult. On the one hand, the ILBI is facing the status quo of "divided governance" between the water column and the international seabed areas, which further leads to possibly apply different governance rules to living resources and mineral resources beyond national jurisdiction. But in the world of the deep sea, minerals and organisms are usually inseparable, that is, they are two aspects of one thing and should be managed as a whole (Tapia et al., 2018). Consequently, the application of different rules is inconsistent with the laws of nature, artificially increasing the difficulties of coordination and may to a certain extent reduce the effectiveness of marine biodiversity protection. On the other hand, if the ILBI were to adopt a regional model and authorize the regional bodies to establish, manage and review the high seas MPAs, the laws of nature that ocean creatures and their communities are moving all the time is also ignored. Thus, the approaches by dividing the marine ecosystem into different areas are no help to protect the marine biological diversity and further deepens the degree of fragmentation of existing international frameworks.

Third, apart from deepening fragmentation of international frameworks, a regional and sectoral model cannot provide the basis of international law for the establishment of MPAs in areas beyond national jurisdiction. In addition, a regional and sectoral model easily leads to a crisis of trust. For example, in the process of establishing the Ross Sea protected areas, Russia, Ukraine, China and other states raised doubts about the legal capacity of CCAMLR in establishing MPAs and lacking a definition of MPA at the annual CCAMLR conference. In 2012 and 2013, Russia even pointed that it would refuse further negotiations if the two issues were not resolved (Shoda et al., 2017). Moreover, in 2014, Russia submitted a working paper "Marine Protected Areas in the Antarctic Treaty System" to the Antarctic Treaty Consultative Meeting (ATCM) and stated that "Taking into account that seven countries of those which have signed the Antarctic Treaty and the CCAMLR Convention have earlier declared territorial claims to Antarctica, Russia is obliged to consider the potential possibility that an MPA may be used as an instrument to establish geopolitical control over southern polar regions over 
which territorial claims were made earlier" (Botte, 2017). It can be seen that the legitimacy of the high seas MPAs is vulnerable to be challenged when the regional model is not authorized at the global level. The non-contracting parties of the RFMO may concern about their freedoms on the high seas which will be imposed further restrictions by the RFMO.

Final, the main purpose of a hybrid model is to provide guidance and legal basis for regional bodies or the RFMO through the ILBI, which cannot avoid the defects of the regional model mentioned above. Moreover, as a compromise, the effectiveness of a hybrid model is difficult to guarantee and the relationship between a global framework and regional organizations is not easy to put in order. If we can solve this problem, hybrid model may be a good choice.

To sum up, the advantages of the global model are obvious, and it is foreseeable that ILBI should finally establish a global governance model for MPAs.

\section{Conclusion}

As a breakthrough to the traditional marine management tools, MPAs are becoming an important means for the international community to protect marine biodiversity. The negotiation of the issue of MPAs in ABNJ will, after dealing with dilemmas of lack of definition, unclear selection criteria, and disputes over the governance model, inevitably reach a reasonable institutional framework, and further promote marine biodiversity protection. The above is only a preliminary discussion on this issue. In the future, specific planning and implementation measures are needed to make this problem better solved.

\section{REFERENCES}

[1] Abdullah, N. A., Rahim, F. (2018): Distinctiveness And Potentials Of Two Flowering Roadside Hedgerows, Turnera Ulmifolia And Melastoma Malabathricum As Benefecial Plants For linsects. - Environment \& Ecosystem Science 2(2): 06-10.

[2] Afonso, P., Schmiing, M., Fontes, J., Tempera, F., Morato, T., Santos, R. S. (2018): Effects of marine protected areas on coastal fishes across the n, mid-north atlantic. Journal of Sea Research 138: 34-47.

[3] Alger, J., Dauvergne, P. (2017): The politics of pacific ocean conservation: lessons from the pitcairn islands marine reserve. - Pacific Affairs 90(1): 29-50.

[4] Ayer, A., Fulton, S., Caamal-Madrigal, J. A., Espinoza-Tenorio, A. (2018): Halfway to sustainability: management lessons from community-based, marine no-take zones in the mexican caribbean. - Marine Policy 93: 22-30.

[5] Ban, N. C., Davies, T. E., Aguilera, S. E., Brooks, C., Cox, M., Epstein, G., Evans, L. S., Maxwell, S. M., Nenadovic, M. (2017): Social and ecological effectiveness of large marine protected areas. - Global Environmental Change 43: 82-91.

[6] Bokuniewicz, H., Jang, S. G. (2018): Dredging intensity: a spatio-temporal indicator for managing marine resources. - Environmental Management 62(5): 1-8.

[7] Botte, E. (2017): Exploiting the sea. annalisa marzano, harvesting the sea. the exploitation of marine resources in the roman mediterranean (oxford studies on the roman economy; oxford 2013). - Journal of Roman Archaeology 28: 684-687.

[8] Cabral, R. B., Gaines, S. D., Johnson, B. A., Bell, T. W., White, C. (2017): Drivers of redistribution of fishing and non-fishing effort after the implementation of a marine protected area network. - Ecological Applications 27(2): 416-428. 
[9] Carr, M. H., Robinson, S. P., Wahle, C., Davis, G., Kroll, S., Murray, S., Schumacker, E. J., Williams, M. (2017): The central importance of ecological spatial connectivity to effective coastal marine protected areas and to meeting the challenges of climate change in the marine environment. - Aquatic Conservation Marine \& Freshwater Ecosystems 27(2): 6-29.

[10] Dias, M. P., Bond, A. L., Carneiro, A. P. B., Lascelles, B., Small, C., Gonzã Lezsolã, S. J. (2017): Using globally threatened pelagic birds to identify priority sites for marine conservation in the south atlantic ocean. - Biological Conservation 211: 76-84.

[11] Duarte, F., Doherty, G., Nakazawa, P. (2017): Redrawing the boundaries: planning and governance of a marine protected area - the case of the exuma cays land and sea park. Journal of Coastal Conservation 21(2): 265-271.

[12] Feng, C., Xu, M., Feng, C., Wettberg, E. J. B. V., Kang, M. (2017): The complete chloroplast genome of primulina and two novel strategies for development of high polymorphic loci for population genetic and phylogenetic studies. - Bmc Evolutionary Biology 17(1): 224.

[13] Ferrari, R., Marzinelli, E. M., Ayroza, C. R., Jordan, A., Figueira, W. F., Byrne, M., Malcolm, H. A., Williams, S. B., Steinberg, P. D. (2018): Large-scale assessment of benthic communities across multiple marine protected areas using an autonomous underwater vehicle. - Plos One 137(1): 1-11.

[14] Gonson, C., Pelletier, D., Alban, F., Giraud-Carrier, C., Ferraris, J. (2017): Influence of settings management and protection status on recreational uses and pressures in marine protected areas. - Journal of Environmental Management 200: 170-185.

[15] Havermans, C., Seefeldt, M. A., Held, C. (2018): A biodiversity survey of scavenging amphipods in a proposed marine protected area: the filchner area in the weddell sea, antarctica. - Polar Biology 41(18): 1-20.

[16] Hughes, K. A., Grant, S. M. (2017): The spatial distribution of antarctica's protected areas: a product of pragmatism, geopolitics or conservation need? - Environmental Science \& Policy 72: 41-51.

[17] Ilyas, F., Arif, M., Iftikhar, A., Sattar, A., Cuong, D. M., Ilyas, M., Parveen, A. (2018): Indigenous Vesicular Mycorrhizal Fungi Effect on Maize Under Different Textures. Earth Sciences Pakistan 2(2): 12-15.

[18] Jabour, J., Smith, D. (2018): The ross sea region marine protected area: can it be successfully managed? - Ocean Yearbook Online 32(1): 190-205.

[19] Kay, S., Butenschön, M. (2018): Projections of change in key ecosystem indicators for planning and management of marine protected areas: an example study for european seas. - Estuarine Coastal \& Shelf Science 201(3): 129-136.

[20] Khanchoul, K., Saaidia, B., Altschul, R. (2018): Variation in Sediment Concentration and Water Disharge During Storm Events in Two Catchments, Northeast of Algeria. - Earth Sciences Malaysia 2(2): 01-09.

[21] Laffoley, D., Freestone, D. (2017): A world of difference - opportunities for applying the 1972 world heritage convention to the high seas. - Aquatic Conservation Marine \& Freshwater Ecosystems 27(6): 78-88.

[22] Lambert, C., Virgili, A., Pettex, E., Delavenne, J., Toison, V., Blanck, A., Ridoux, V. (2017): Habitat modelling predictions highlight seasonal relevance of marine protected areas for marine megafauna. - Deep Sea Research Part II Topical Studies in Oceanography 141: 262-274.

[23] Lathrop, R. G., Bognar, J., Buenaventura, E., Ciappi, M., Green, E., Belton, T. J. (2017): Establishment of marine protected areas to reduce watercraft impacts in barnegat bay, new jersey. - Journal of Coastal Research 78: 277-286.

[24] Madrigal-Ballestero, R., Albers, H. J., Capitán, T., Salas, A. (2017): Marine protected areas in costa rica: how do artisanal fishers respond? - Ambio 46(4): 1-10. 
[25] Majumder, S. C., Islam, K., Hossain, M. M. (2019): State of research on carbon sequestration in Bangladesh: a comprehensive review. - Geology, Ecology, and Landscapes 3(1): 29-36.

[26] Mazaris, A. D. (2017): Manifestation of maritime piracy as an additional challenge for global conservation. - Marine Policy 77(Complete): 171-175.

[27] Mcneill, A., Clifton, J., Harvey, E. S. (2018): Attitudes to a marine protected area are associated with perceived social impacts. - Marine Policy 94(3): 106-118.

[28] Mrema, E. (2017): Introduction: protecting the global commons. - Georgetown Journal of International Affairs 18(1): 3-5.

[29] Nikitine, J., Wilson, A. M. W., Dawson, T. P. (2018): Developing a framework for the efficient design and management of large scale marine protected areas. - Marine Policy 94: 196-203.

[30] Nouaim, W., Chakiri, S., Rambourg, D., Karaoui, I., Ettaqy, A., Chao, J., Allouza, M., Razoki, B., Yazidi, M., Hmidi, F. E. (2019): Mapping the water erosion risk in the Lakhdar river basin (central High Atlas, Morocco). - Geology, Ecology, and Landscapes 3(1): 22-28.

[31] Omini, E. O., Akpang, O. M. (2018): Cavity Detection Under Re-Enforced Concrete Floor Using Ground Penetration Radar. - Engineering Heritage Journal 2(2): 11-18.

[32] Pereira, J. M., Krüger, L., Oliveira, N., Meirinho, A., Silva, A., Ramos, J. A., Paiva, V. H. (2018): Using a multi-model ensemble forecasting approach to identify key marine protected areas for seabirds in the portuguese coast. - Ocean \& Coastal Management 153: 98-107.

[33] Plassjohnson, J., Mcquaid, C., Porri, F. (2017): Top-down effects on intertidal mussel populations: assessing two predator guilds in a south african marine protected area. Marine Ecology Progress 411(6): 149-159.

[34] Postaire, B., Gélin, P., Bruggemann, H., Pratlong, M., Magalon, H. (2017): Population differentiation or species formation across the indian and the pacific oceans? an example from the brooding marine hydrozoanmacrorhynchia phoenicea. - Ecology \& Evolution 7(20): 8170-8186.

[35] Qiao, F. (2018): The Study On The Integration Of Green Architecture And Appropriate Technology. - Engineering Heritage Journal 2(2): 01-03.

[36] Rahim, Y., Khan, M. S., Mughal, S. (2018): Petrography Of Sandstone Of The Lumshiwal Formation From Eastern Hazara, Khyber Pakhtunkhwa, Pakistan: Implications For Provenance, Diagenesis And Environments Of Deposition. - Earth Sciences Pakistan 2(2): 01-06.

[37] Sarwar, M. T., Hui, Z. H., Maqbool, A. (2019): Causes And Control Measures Of Urban Air Pollution In China. - Environment \& Ecosystem Science 3(1): 35-36.

[38] Schulze, A., Grimes, C. J., Rudek, T. E. (2017): Tough, armed and omnivorous: hermodice carunculata (annelida: amphinomidae) is prepared for ecological challenges. Journal of the Marine Biological Association of the United Kingdom 97: 1-6.

[39] Shoda, S., Lucquin, A., Ahn, J. H., Hwang, C. J., Craig, O. E. (2017): Pottery use by early holocene hunter-gatherers of the korean peninsula closely linked with the exploitation of marine resources. - Quaternary Science Reviews 170: 164-173.

[40] Soares, M. D. O., Lucas, C. C. (2018): Towards large and remote protected areas in the south atlantic ocean: st. peter and st. paul's archipelago and the vitória-trindade seamount chain. - Marine Policy 93: 101-103.

[41] Solovyev, B., Spiridonov, V., Onufrenya, I., Belikov, S., Chernova, N., Dobrynin, D., Gavrilo, M., Glazov, D., Krasnov, Y., Mukharamova, S., Pantyulin, A., Platonov, N., Saveliev, A., Stishovm M., Tertitski, G. (2017): Identifying a network of priority areas for conservation in the arctic seas: practical lessons from Russia. - Aquatic Conservation Marine \& Freshwater Ecosystems 27(Supplement S1): 30-51. 
[42] Sufiyan, I., Zakariya, R., Yacoob, R., Idris, M. S., Idris, N. M. (2018): SWAT Subbasins Parameters and Flood Risk Simulations Using 3d In Terengganu Watershed. - Earth Sciences Malaysia 2(2): 10-15.

[43] Tagle, V. (2018): Characterization of two natural sorbents for the evaluation of metal contamination in water. - Acta Microscopica 27(3).

[44] Tapia-Monsalve, R., Newsome, S. D., Sanchez-Hernandez, J. C., Bozinovic, F., Nespolo, R., Sabat, P. (2018): Terrestrial birds in coastal environments: metabolic rate and oxidative status varies with the use of marine resources. - Oecologia: 1-9.

[45] Tommasi, D., Stock, C. A., Hobday, A. J., Methot, R., Kaplan, I. C., Eveson, J. P., Holsman, K., Miller, T. J., Gaichas, S., Gehlen, M., Pershing, A., Vecchi, G. A., Msadek, R., Delworth, T., Eakin, C. M., Haltuch, M. A., Séférian, R., Spillman, C. M., Werner, F. E. (2017): Managing living marine resources in a dynamic environment: the role of seasonal to decadal climate forecasts. - Progress in Oceanography 152: 15-49.

[46] Urra, J., Rueda, J. L., Marina, P., Antit, M., Salas, C. (2018): Populations of commercial molluscs within a highly biodiverse marine protected area of the northern alboran sea (w mediterranean): preferential habitats, seasonal dynamics and importance for artisanal fisheries. - Thalassas An International Journal of Marine Sciences 34(4): 1-11.

[47] Wang, Z., Wang, X., Wang, J. (2018): Recent advances in antibacterial and antiendotoxic peptides or proteins from marine resources. - Marine Drugs 16(2): 57.

[48] Wu, L. (2018): A Review of 300,000 Foreign Students Plan of Japan over the Past Decade (2008-2017): Analysis based on International Students in Japan by JASSO. - Argos 35(71).

[49] Young, M., Friedman, A. (2018): Biodiversity beyond national jurisdiction: regimes and their interaction. - AJIL Unbound 112: 123-128. 